\title{
Immunodetection of some pectic, arabinogalactan proteins and hemicellulose epitopes in the micropylar transmitting tissue of apomictic dandelions (Taraxacum, Asteraceae, Lactuceae)
}

\author{
Robert Gawecki $^{1} \cdot$ Katarzyna Sala $^{1}$ - Ewa U. Kurczyńska ${ }^{1} \cdot$ Piotr Świątek $^{2}$. \\ Bartosz J. Plachno ${ }^{3}$
}

Received: 5 January 2016 / Accepted: 29 April 2016 / Published online: 6 May 2016

(C) The Author(s) 2016. This article is published with open access at Springerlink.com

\begin{abstract}
In apomictic Taraxacum species, the development of both the embryo and the endosperm does not require double fertilisation. However, a structural reduction of ovular transmitting tissue was not observed in apomictic dandelions. The aim of this study was to analyse the chemical composition of the cell walls to describe the presence of arabinogalactan proteins (AGPs), hemicellulose and some pectic epitopes in the micropylar transmitting tissue of apomictic Taraxacum. The results point to (1) the similar distribution of AGPs in different developmental stages, (2) the absence of highly methylesterified homogalacturonan (HG) in transmitting tissue of ovule containing a mature embryo sac and the appearance of this pectin domain in the young seed containing the embryo and endosperm, (3) the similar pattern of low methylesterified pectin occurrence in both an ovule and a young seed with an embryo and endosperm in apomictic Taraxacum and (4) the presence of hemicelluloses recognised by LM25 and LM21 antibodies in the reproductive structure of Taraxacum.
\end{abstract}

Handling Editor: David McCurdy

Electronic supplementary material The online version of this article (doi:10.1007/s00709-016-0980-0) contains supplementary material, which is available to authorized users.

Bartosz J. Płachno

bartosz.plachno@uj.edu.pl

1 Department of Cell Biology, Faculty of Biology and Environmental Protection, University of Silesia, 28 Jagiellońska St., 40-032 Katowice, Poland

2 Department of Animal Histology and Embryology, University of Silesia, 9 Bankowa St., 40-007 Katowice, Poland

3 Department of Plant Cytology and Embryology, Jagiellonian University in Kraków, 9 Gronostajowa St., 30-387 Kraków, Poland
Keywords Ovule · Transmitting tissue - Gynoecium · Dandelions · Asteraceae - Apomixis - Arabinogalactan proteins $\cdot$ Pectins $\cdot$ Hemicellulose $\cdot$ Taraxacum

\section{Introduction}

The stylar and ovule transmitting tissues form the environment and guidance for the growth of a pollen tube (male gametophyte) into a female gametophyte. The transmitting tissue is composed of a stigma, style and the adaxial carpel epidermis within the ovary locule and, frequently, a funiculus (forming obturator) (e.g. Vasil and Johri 1964; Tilton and Horner 1980; Lyew et al. 2007). The stylar transmitting tissue is anatomically and histochemically similar to the dry stigma (Sage et al. 2009). The most prominent character of this tissue is the extracellular matrix (ECM), which consists of intercellular spaces filled with a secretion as well as the walls of the transmitting tissue cells (Lord 2003). From an evolutionary perspective, the presence of a well-developed transmitting tissue in the basal angiosperms such as Amborella trichopoda, Illicium floridanum, Trimenia moorei and Acorus americanus suggests its ancient role in the evolution of flowering plants (Sage et al. 2009). The ECM contains compounds (including calcium, lipids, arabinogalactan proteins (AGPs), a lipid-like transfer proteins and methyl-esterified homogalacturonan), which facilitate, and also guide, the adhesion and growth of the pollen tubes (e.g. Wu et al. 2000; Lord and Russell 2002; Khosravi et al. 2003; Lenartowska et al. 2001; Coimbra and Duarte 2003; Sage et al. 2009). AGPs are not only involved in sexual plant reproduction but may also be useful markers for gametophytic cell differentiation (e.g. Coimbra and Salema 1997; Coimbra and Duarte 2003; Coimbra et al. 2007, 2008; Wiśniewska and Majewska-Sawka 2006; Rafińska and Bednarska 2011; Chudzik et al. 2014) and ovule receptivity 
(Coimbra and Duarte 2003; Chudzik 2002; Śnieżko and Chudzik 2003; Chudzik et al. 2005b). In fertile and mature angiosperm ovules, epitopes that were recognised by the JIM8 or JIM13 antibodies were detected on the micropylar pole in the tissues lying on the pathway of pollen tube growth (Coimbra and Salema 1997; Śnieżko and Chudzik 2003; Chudzik et al. 2005b; Coimbra et al. 2007); thus, the AGPs recorded in this localisation may act as lubricants and/or nutrients for the pollen tube (Suárez et al. 2013). Similar to AGPs, an accumulation of homogalacturonan in both esterified and unesterified forms was found in the tissues lying on the pathway of the pollen tube growth only in fertile and mature ovules (Chudzik 2002; Śnieżko and Chudzik 2003; Niedojadło et al. 2015). The question is whether the accumulation of arabinogalactan proteins and homogalacturonan occurs in the micropyle of obligatory apomicts, in which the development of both the embryo and the endosperm does not require double fertilisation. To date, there is only one species that has been examined from this group-Chondrilla juncea L. (Kościńska-Pająk et al. 2005; Kościńska-Pająk 2006; Chudzik et al. 2005a). According to these authors, both esterified and deesterified pectins were abundant in the micropylar canal matrix but were not present in the micropylar part of the embryo sac. Moreover, there was a lack of AGP epitopes that were recognised by the JIM13 antibody inside the micropylar canal and mature embryo sac in $C$. juncea. Thus, the occurrence of AGPs and homogalacturonan has mostly been determined in the ovules in amphimictic species and data about apomicts are fragmentary and unsatisfactory. Recently, the anatomy and ultrastructure of the transmitting tissue was analysed in apomictic Taraxacum species, and no major differences were detected between the micropyle structure of the amphimictic and apomictic Taraxacum (Płachno et al. 2015a, b).

We would like to highlight that over 24,000 species are recognised in the Asteraceae family (Funk et al. 2009), but so far, the immunohistochemistry of the cell walls in the ovule tissue/embryo sac has been described only for two species (C. juncea and Bellis perennis) from this family. Therefore, the aim of our study was to check whether and which AGPs, pectic and hemicellulose epitopes occur in the micropylar transmitting tissue of apomictic Taraxacum. None of the studies on Asteraceae family gives as a full picture of immunochemistry of cell walls in micropylar transmitting tissue and synergids as we present here on the example of Taraxacum. Such knowledge about the chemical composition of cell walls or its changes might be used (in the future) to explain the mechanisms underlying different ways of reproduction (apomictic and sexual).

\section{Material and methods}

The material was represented by apomictic taxa from the Taraxacum sect. Taraxacum (Taraxacum officinale agg., collected in Katowice, Silesia, Poland, and also from the collection of the Department of Plant Cytology and Embryology, Jagiellonian University). Studies were carried out on flowers before and during anthesis. The flowers of the apomictic species harvested before anthesis contained a mature embryo sac (Fig. 1a, b), whereas the flowers harvested during anthesis already contained an embryo and endosperm (Fig. 1c, d) as it was previously observed (Płachno et al. 2014; Płachno et al. 2015a, b).

Individual ovaries were collected with a razor blade under an Olympus SZH10 stereomicroscope and fixed in a mixture of $3 \%(w / v)$ paraformaldehyde (PFA), $1.25 \%(v / v)$ glutaraldehyde (GA), $1 \%(w / v)$ sucrose and $0.1 \%(w / v)$ Triton X-100 in phosphate-buffered saline (PBS; $\mathrm{pH}$ 7.4). To remove the air from the material and to facilitate fixative infiltration, samples were put under a vacuum for $5 \times 15 \mathrm{~min}$ bursts. The samples were fixed overnight at $4{ }^{\circ} \mathrm{C}$ and then rinsed with PBS $(3 \times 15 \mathrm{~min})$, dehydrated in an ethanol series $(10,30,50,70$, 90 and $100 \%, v / v$ ) and embedded in Steedman's wax according to Vitha et al. (2000). Material was cut into 7- $\mu \mathrm{m}$-thick sections using a Zeiss Hyrax M40 microtome. Sections were collected on microscopic slides covered with Mayer's adhesive albumin (Potocka et al. 2012; Sala et al. 2013). Before staining procedures, the sections were dewaxed and rehydrated in a successive ethanol series (three times in 100, 90 and $50 \%$ in PBS $(v / v), 10$ min each).

\section{Histochemistry}

For general histology, the sections were stained with a $0.05 \%$ aqueous solution of Toluidine Blue O for $5 \mathrm{~min}$. A $0.02 \%$ aqueous solution of ruthenium red was used to detect pectin (10 min staining) and a $0.02 \%$ aqueous solution of neutral red to confirm the presence of mucilage ( 5 min staining). All slides were mounted with a $50 \%(v / v)$ aqueous glycerol solution, observed and photographed with a Nikon Eclipse Ni-U microscope equipped with a Nikon Digital DS-Fi1-U3 camera (Nikon, Tokyo, Japan).

\section{Immunocytochemistry}

Sections were blocked in a buffer containing $2 \%(v / v)$ foetal calf serum (FCS) and $2 \%(w / v)$ bovine serum albumin (BSA) in PBS (pH 7.2, room temperature (RT), $30 \mathrm{~min}$ ). Next, the sections were incubated with primary monoclonal antibodies (see Table 1), diluted 1:20 in a blocking buffer (RT, minimum $1.5 \mathrm{~h}$ ), rinsed with the blocking buffer (three times, $10 \mathrm{~min}$ each) then incubated with the secondary antibody (Alexa Fluor 488 goat anti-rat IgG, Jackson Immuno-Research Laboratories, West Grove, USA) and diluted 1:100 in the blocking buffer (RT, minimum $1.5 \mathrm{~h}$ ). After washing (three times, 10 min each) with the blocking buffer and PBS, the sections were stained with $0.01 \%(w / v)$ fluorescent 
Fig. 1 Section through the ovule and young seed of Taraxacum showing the developmental stages. a, b Section through the ovule from a flower harvested before anthesis, showing a mature embryo sac with the egg apparatus (black arrows), synergid filiform apparatus (open arrow), micropylar transmitting tissue cells (black star) and mucilage cells $(M)$, bar $=20 \mu \mathrm{m}$. c, d Section through a young seed from a flower harvested during anthesis, showing the embryo (em), endosperm $(e)$ and micropylar transmitting tissue cells (black star), bar $=100 \mu \mathrm{m}$
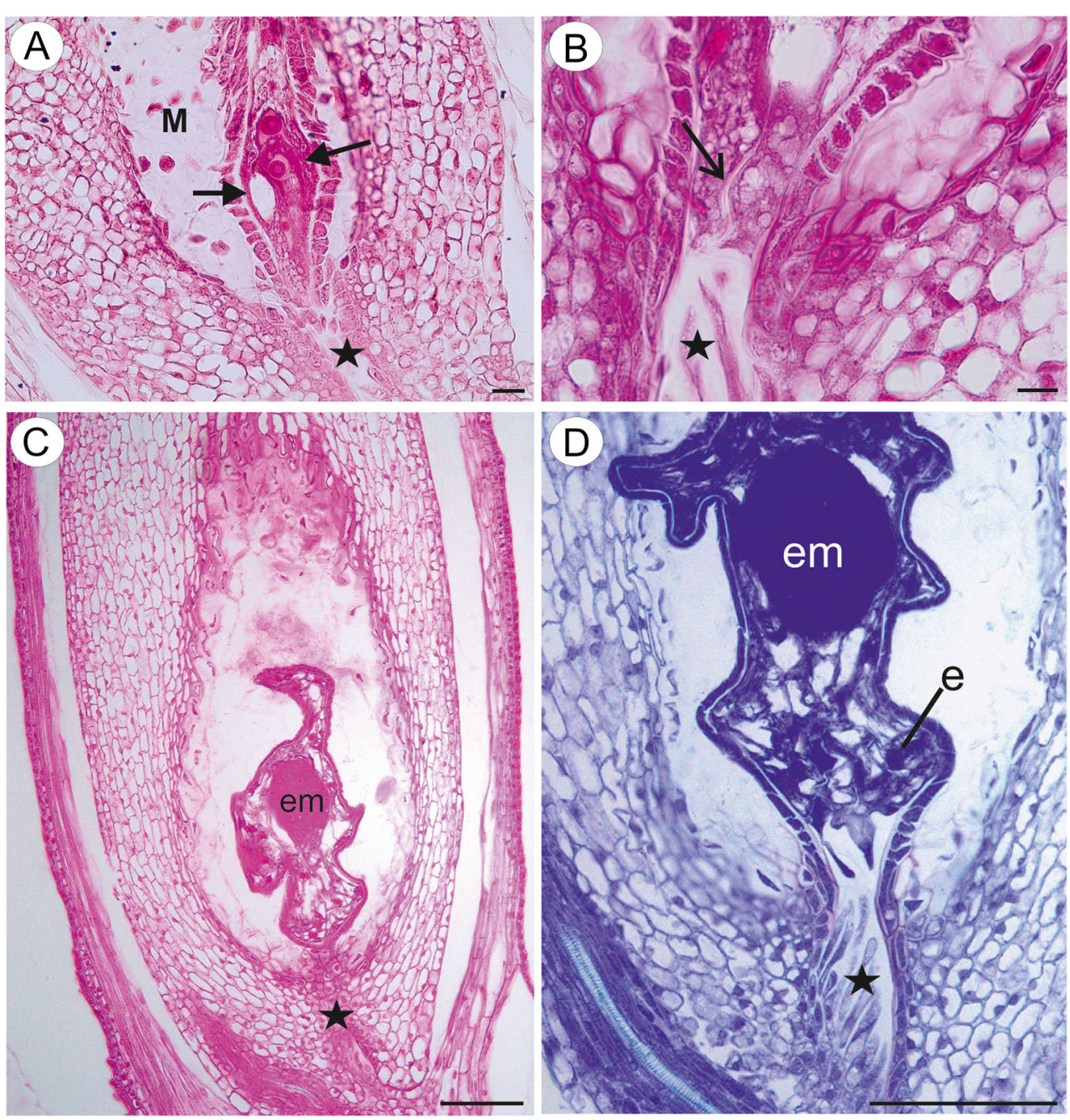

Table 1 List of the monoclonal antibodies used in the current study, the epitopes they recognised and references
Antibody Epitope References

Hemicelluloses

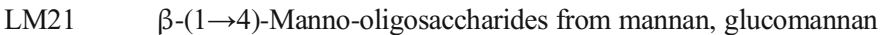
and galactomannan

LM25 XLLG, XXLG and XXXG motifs of xyloglucan

Pectins

LM19 HG domain in pectic polysaccharides, recognises a range of $\mathrm{HG}$ with the preference to bind strongly to unesterified $\mathrm{HG}$

LM20 HG domain in pectic polysaccharides, requires methyl esters for recognition of $\mathrm{HG}$ and does not bind to unesterified $\mathrm{HG}$

LM8 Xylogalacturonan (HG domain)

JIM5 HG domain of pectic polysaccharides, recognises partially methylesterified epitopes of $\mathrm{HG}$, can also bind to unesterified HG

JIM7 HG domain of pectic polysaccharides, recognises partially methylesterified epitopes of HG but does not bind to unesterified HG

AGPs

JIM8

Arabinogalactan

JIM13 Arabinogalactan/arabinogalactan protein

JIM16 Arabinogalactan/arabinogalactan protein
Marcus et al. 2010

Pedersen et al. 2012

Verhertbruggen et al. 2009, www.plantprobes.net

Verhertbruggen et al. 2009, www.plantprobes.net

Willats et al. 2004

Knox et al. 1990, www.plantprobes.net

Knox et al. 1990, www.plantprobes.net

Pennell et al. 1991

Knox et al. 1991

Knox et al. 1991 
brightener 28 (Sigma, St. Louis, USA) in PBS for 5 min, rinsed with PBS and distilled sterile water (four times, $5 \mathrm{~min}$ for each), shaken dry and mounted with a Fluoromount (Sigma, St. Louis, USA) anti-fading medium. Some sections were stained with both fluorescent brightener 28 (Sigma, St. Louis, USA) and with DAPI (4',6-diamidino-2-phenylindole; Invitrogen Inc.; $2 \mu \mathrm{g} / \mathrm{ml}$, RT, $5 \mathrm{~min}$ ). Negative controls were performed by omitting the primary antibody step, obtaining no fluorescence signal in each control frame for all slides stained.

Observations and photography were carried out with a Nikon Eclipse Ni-U microscope (or an Olympus BX60 microscope) equipped with a Nikon Digital DS-Fi1-U3 camera with corresponding software (Nikon, Tokyo, Japan) and filters for Alexa Fluor 488 (excitation filter 450-490, barrier filter BA520), fluorescent brightener 28 and DAPI (excitation filter 330-380, barrier filter BA420). Sections labelled with the JIM13 antibody were also imaged using an Olympus Fluoview FV1000 laser scanning microscope. The excitation wavelength for the Alexa Fluor 488 was $488 \mathrm{~nm}$, and the emission was collected at 500 to $545 \mathrm{~nm}$. A maximum intensity projection was generated using ImageJ software (version 1.49; http://imagej.nih.gov/).

\section{Transmission electron microscopy}

Preparation of the samples for transmission electron microscopy (TEM) followed the procedure used by Płachno et al. (2014). The sections were examined using a Hitachi H500 electron microscope at $75 \mathrm{kV}$ in the Faculty of Biology and Environmental Protection, University of Silesia in Katowice.

\section{Results}

\section{Ovules containing a mature embryo sac}

The AGP detected by the JIM13 antibody was present in the cytoplasm (the term "cytoplasm" in the whole manuscript must be understood as an abbreviation form of "localization within the cytoplasm endomembrane system", not directly in the cytoplasm; but as an analysis was performed on the light microscope level, determination of which kind of membranes was involved was not possible; moreover, this statement indicates the cytoplasmic localisation in the close proximity to the plasma membrane because the vicinity of the cell wall suggests such interpretation) and cell wall of the integument cells near the egg apparatus, the integument cells surrounding the micropylar canal (Fig. 2a, b), in the central cell and in the synergids (Fig. 2c, d; sup. mat. Fig. 1A, B). The JIM13 was detected in the transmitting tissue cells but in a much lower amount (Fig. 2a; sup. mat. Fig. 1). In contrast, the AGP recognised by the JIM16 antibody was present only in the parietal layer of cytoplasm of the integument cells surrounding the micropylar canal, the apex of the synergids and the transmitting tissues, where this epitope was also detected in cell walls (Fig. 2e, f). Moreover, the JIM16 antibody was present in the borders between the cells of the egg apparatus and the central cell (Fig. 2f). The AGP recognised by the JIM8 antibody was not detected in any of the analysed cells in both developmental stages.

The pectic epitope recognised by the JIM5 antibody was abundantly present in the walls of different integument cells, the extracellular matrix of the transmitting tissue cells, although it was absent from the cytoplasm (Fig. 3a). In some cells, this epitope was also present in the cytoplasm of the integument cells surrounding the micropylar canal, the apex of the synergids and the filiform apparatus of synergids (Fig. 3b). Always such a localisation was in the close proximity to the cell wall (parietal layer of cytoplasm). The LM19 epitope was present mostly in the cell walls of the integument tissues, and the fluorescence was especially strong in the integument tissues near the egg apparatus and in transmitting tissues (Fig. 3c, d). A low amount of this epitope was noted also in the cytoplasmic part of the cell (Fig. 3c, d).

Pectic epitope recognised by the JIM7 antibody was detected in most of the ovule tissues except from the transmitting tissue and the embryo sac (Fig. 3e, f). The LM20 epitope was present in the cell walls of the integumentary tapetum near the central cell of the embryo sac and in the transmitting tissue cells (Fig. 3g, h); however, it was absent from the integumentary cells surrounding the egg apparatus (Fig. 3g, h). The LM8 antibody was not detected in any of the analysed cells independent on the developmental stage. The hemicellulose epitope recognised by the LM21 antibody was detected mostly in the walls of transmitting tissue cells and cytoplasm of some integument cells near the embryo sac and micropylar canal (Fig. 4a, b). The LM25 epitope was present in the integumentary epidermis near the apex of the embryo sac, and the fluorescence was very intense (Fig. 4c). Fluorescence signal was also detected in the cytoplasm and the walls of the transmitting tissue cells (Fig. 4d, e).

\section{A young seed containing an embryo and endosperm}

The AGP epitope recognised by the JIM16 antibody was present in the transmitting tissue cell cytoplasm and in the integumentary cells bordering the micropylar canal (Fig. 5a-c). An intense fluorescence signal was detected in the integumentary epidermal cells of the border of the endosperm (at the micropylar pole; Fig. 5b). The distribution of the JIM13 epitope was the same as in the former described developmental stage (data not shown).

The pectic epitope recognised by the JIM5 antibody was abundantly present in the walls of different integument cells, especially in those surrounding the micropylar canal, and in 
Fig. 2 Arabinogalactan protein detection in an ovule containing a mature embryo sac $(E s)$. a Presence of the JIM13 antibody in micropylar transmitting tissue cells (star), bar $=50 \mu \mathrm{m}$. b The same section as a, cellulose visualisation, bar $=50 \mu \mathrm{m}$. c Presence of the JIM13 antibody in synergids (ss; white star points to the transmitting tissue), bar $=20 \mu \mathrm{m}$. d The same section as c, cellulose visualisation (ss synergids; white star points to the transmitting tissue),

$b a r=20 \mu \mathrm{m}$. e, f Presence of the JIM16 antibody in micropylar transmitting tissue cells (star; eg egg cell, $s$ synergid), bar $=20 \mu \mathrm{m}$
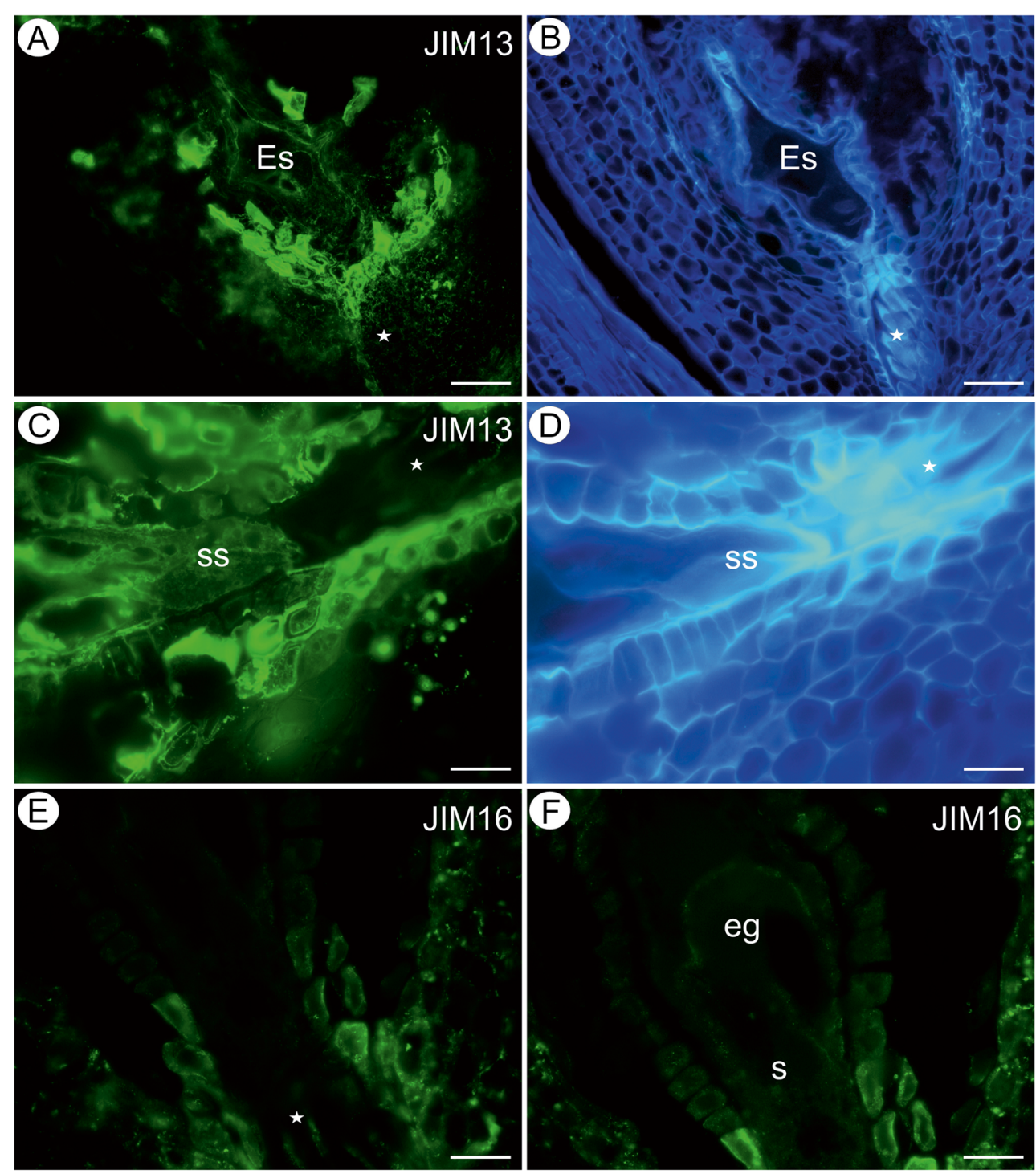

the transmitting tissue cells (Fig. 6a, b). The LM19 epitope occurred in most of the cell walls of the integument tissue cells especially near the micropylar canal (Fig. 6c, d). This epitope was detected in the walls and extracellular matrix of transmitting tissue cells (Fig. 6c, d). The pectic epitope recognised by the JIM7 antibody was present in walls of integument cells and in a very low amount in transmitting tissues cell walls (Fig. 6e, f). The LM20 epitope was detected in the walls of the transmitting tissue cells and in the parenchyma of the integument (Fig. 6g, h).

\section{TEM}

Because we observed the strong labelling of the integument cells at the micropylar pole near the egg apparatus with the JIM13 antibody, the ultrastructure of these cells was studied (Fig. $7 \mathrm{a}-\mathrm{c}$ ). Some of these cells did not produce mucilage and were characterised by dense cytoplasm filled with numerous ribosomes, non-hypertrophied dictyosomes and small vacuoles that sometimes contained some vesicles (Fig. 7a, b). Other cells that produced mucilage had a very dense cytoplasm with hypertrophied dictyosomes (Fig. 7c).

\section{Discussion}

The results presented here concern the distribution of AGP, pectic and hemicellulose epitopes in the reproductive structures of Taraxacum and indicate some spatio-temporal differences and similarities in ovule and seed.

\section{AGPs}

Most of our present knowledge concerning the involvement of AGPs in developmental processes comes from studies on somatic embryogenesis and root organogenesis 
Fig. 3 Pectin detection in an ovule containing a mature embryo sac $(E s)$. a Presence of the JIM5 antibody in micropylar transmitting tissue cells (star), cellulose visualisation (inset), bar $=50 \mu \mathrm{m}$. b Presence of the JIM5 antibody in synergids ( $s S$ synergids; white arrow indicates the synergid filiform apparatus) and micropylar transmitting tissue cells (star), cellulose visualisation (inset), $\mathrm{b} a r=20 \mu \mathrm{m}$.

c Distribution of the LM19 antibody in embryo sac and synergids (ss; inset) and in micropylar transmitting tissue cells (white star), bar $=50 \mu \mathrm{m}$. d The same section as $\mathbf{c}$, cellulose visualisation, bar $=50 \mu \mathrm{m}$. e Distribution of the JIM7 antibody. Note the lack of signal in the transmitting tissue (white star), but the presence of signal in the integumentary cell walls and the chalazal pole (inset), bar $=50 \mu \mathrm{m}$. f The same section as $\mathbf{e}$, cellulose visualisation, bar $=50 \mu \mathrm{m}$. g Distribution of the LM20 antibody (open arrow points to the outer periclinal wall of the tapetum cells). Note the weak signal in the transmitting tissue (white star), but the presence of signal in the integumentary cell walls and the chalazal pole including the epidermis (inset), bar $=50 \mu \mathrm{m}$. $\mathbf{h}$ The same section as $\mathbf{g}$, cellulose visualisation, bar $=50 \mu \mathrm{m}$; bar on all the insertions $=10 \mu \mathrm{m}$
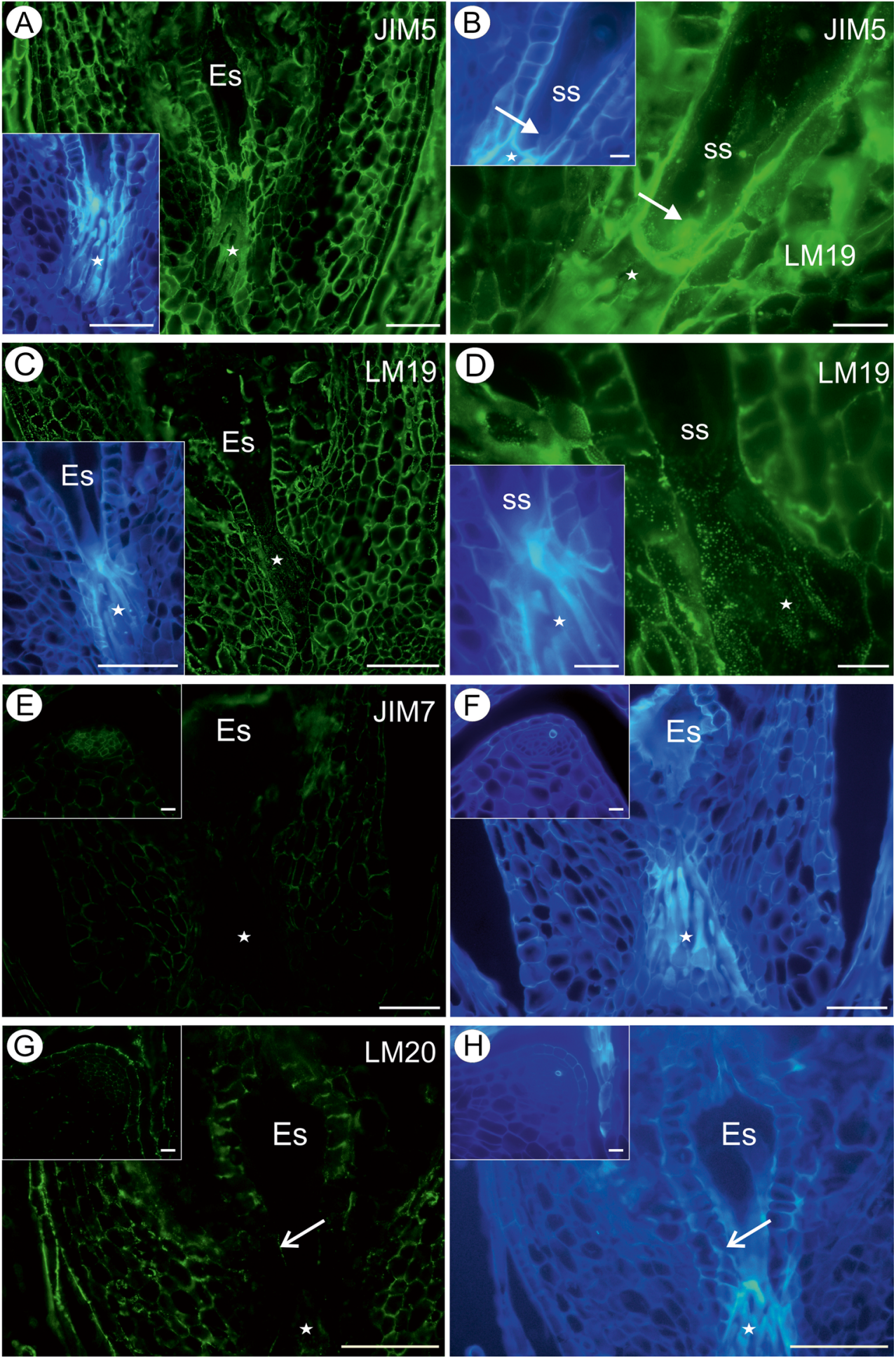

(van Hengel et al. 2002; Rumyantseva 2005; Wilson et al. 2015; Šamaj et al. 1999; Tchorbadjieva 2005; Seifert and Roberts 2007). Results shown in the current studies broaden the knowledge on the putative involvement of AGPs in ovule and seed development on the example of Taraxacum. Arabinogalactan proteins were detected in the ovules of species from different evolutionary lines of angiosperms, e.g. in the early divergent angiosperms Nymphaeales (Trithuria, Hydatellaceae; Costa et al. 2013) and Austrobaileyales (Illicium, Trimenia, Sage et al. 2009) as well as in core eudicots (e.g. Brassica, Pennell et al. 1991; Sinapis, Chudzik et al. 2005a, b; Arabidopsis, Coimbra et al. 2007; Olea, Suárez et al. 2013) and monocots (Galtonia and Galanthus, Chudzik et al. 2005b). 
Fig. 4 Hemicellulose detection in an ovule containing a mature embryo sac $(E s)$.

a Section labelled with the LM21 antibody, micropylar transmitting tissue cells, $b a r=50 \mu \mathrm{m}$. b The same section as a, cellulose visualisation, $b a r=50 \mu \mathrm{m}$. c, d Sections labelled with the LM25 antibody, bar $=50$ and $20 \mu \mathrm{m}$, respectively. e The same as $\mathbf{d}$ but seen in a differential interference contrast, micropylar transmitting tissue cells (star), bar $=20 \mu \mathrm{m}$
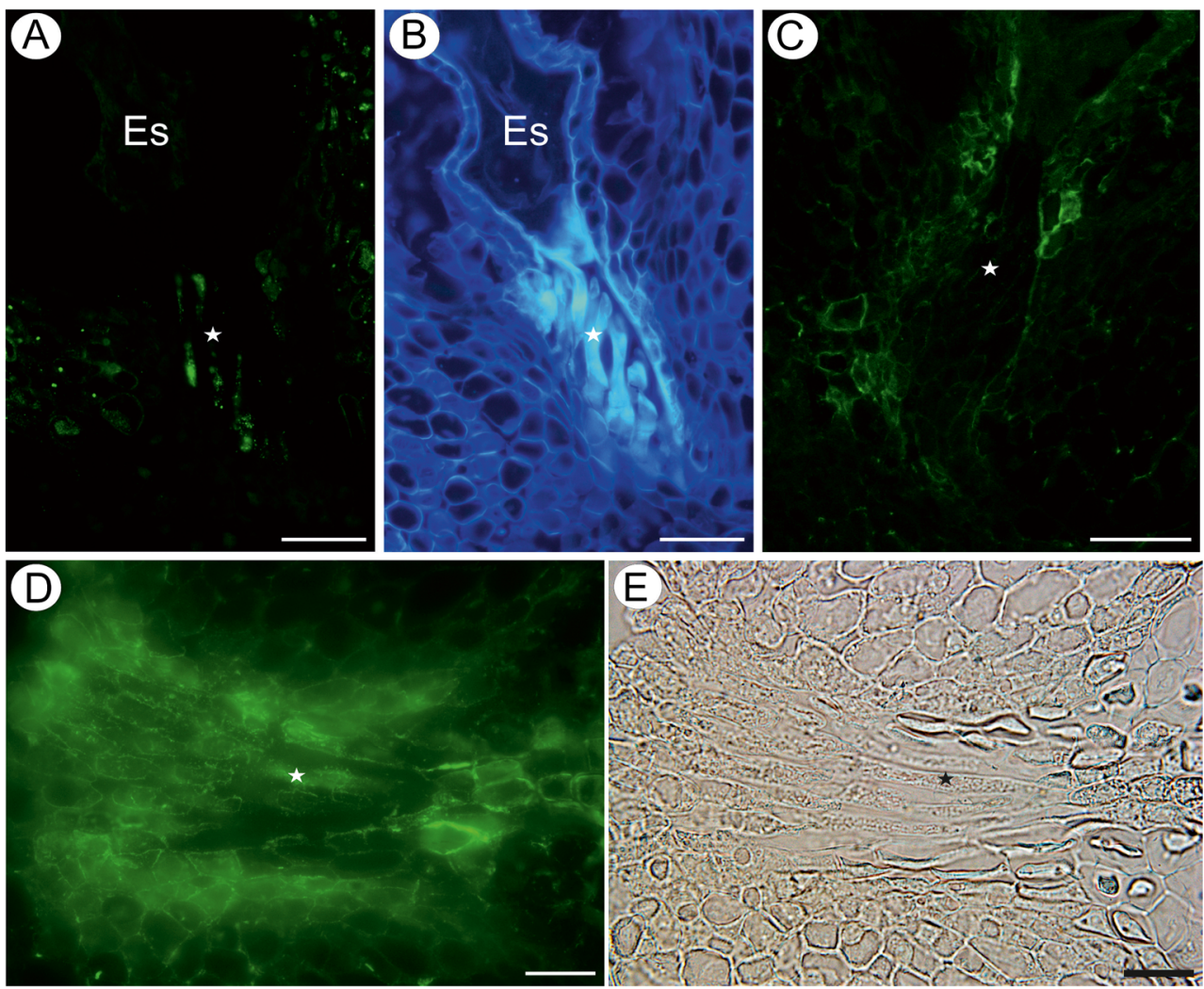

AGPs were detected at the micropylar ovule pole in the tissues lying on the pathway of pollen tube growth. In the crassinucellate ovule type, AGPs were recorded in the micropylar nucellar tissue and the integuments lining the pollen tube growth pathway (Coimbra and Salema 1997; Chudzik et al. 2005a, b). In the tenuinucellate ovule type, AGPs were observed in the integument cells that define the micropyle as in Arabidopsis (Coimbra et al. 2007) or in the micropylar canal as in Galanthus (Chudzik et al. 2005b). In the tenuinucellate ovule of Taraxacum, the intense labelling of JIM13 was seen in the integument cells surrounding the micropylar canal in contrast to the micropylar transmitting tissue cells, which were only slightly labelled. However, AGP epitope recognised by the JIM16 antibody was present in the parietal layer of cytoplasm of the micropylar transmitting tissue cells. The ultrastructure of the integument cells surrounding the micropylar canal was previously analysed by Płachno and co-authors (2015a). The exocytosis of various vesicles was observed in these cells. Thus, given the occurrence of AGP (both JIM13 and JIM16 epitopes) and the ultrastructure data, it is suggested that these cells may also participate in interactions with the pollen tubes (in sexual Taraxacum and, in rare cases, in apomicts, see Małecka 1973; van Baarlen et al. 2002; Mártonfiová 2006). An interesting result presented here is the strong labelling of integument cells near the egg apparatus with the JIM13 antibody. These cells border the fully
Fig. 5 Distribution of arabinogalactan proteins in a seed containing an embryo and endosperm. a, b Distribution of the JIM16 antibody in micropylar transmitting tissue cells, bar $=20 \mu \mathrm{m}$. c The same as b but seen in a differential interference contrast (star micropylar transmitting tissue cells), bar $=20 \mu \mathrm{m}$
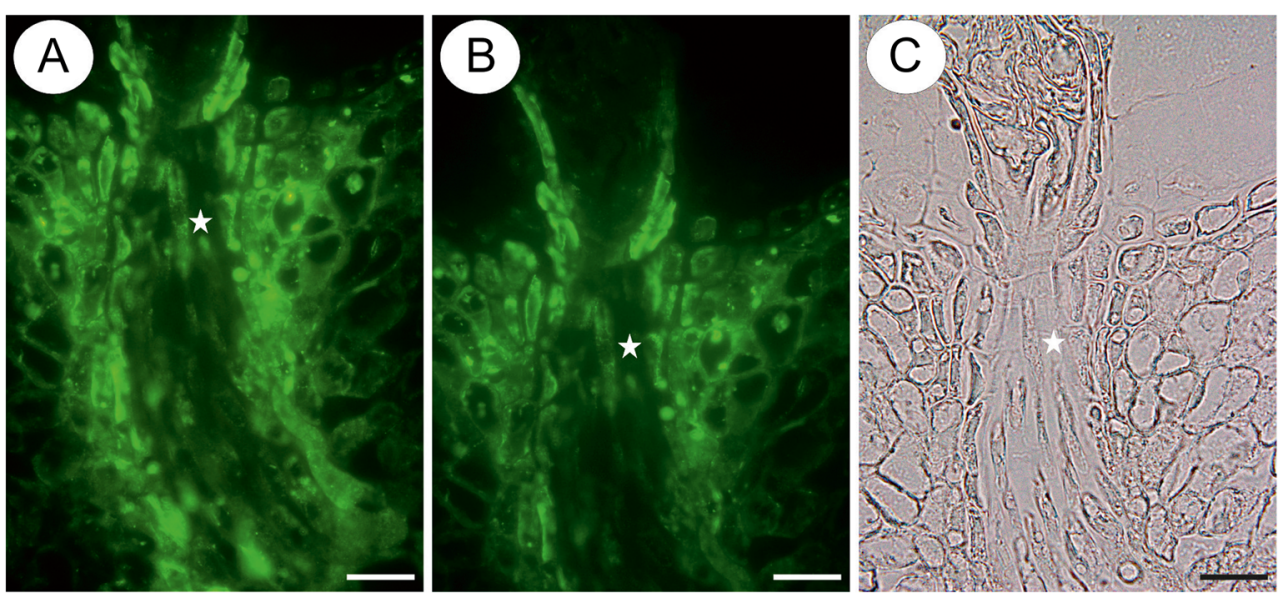

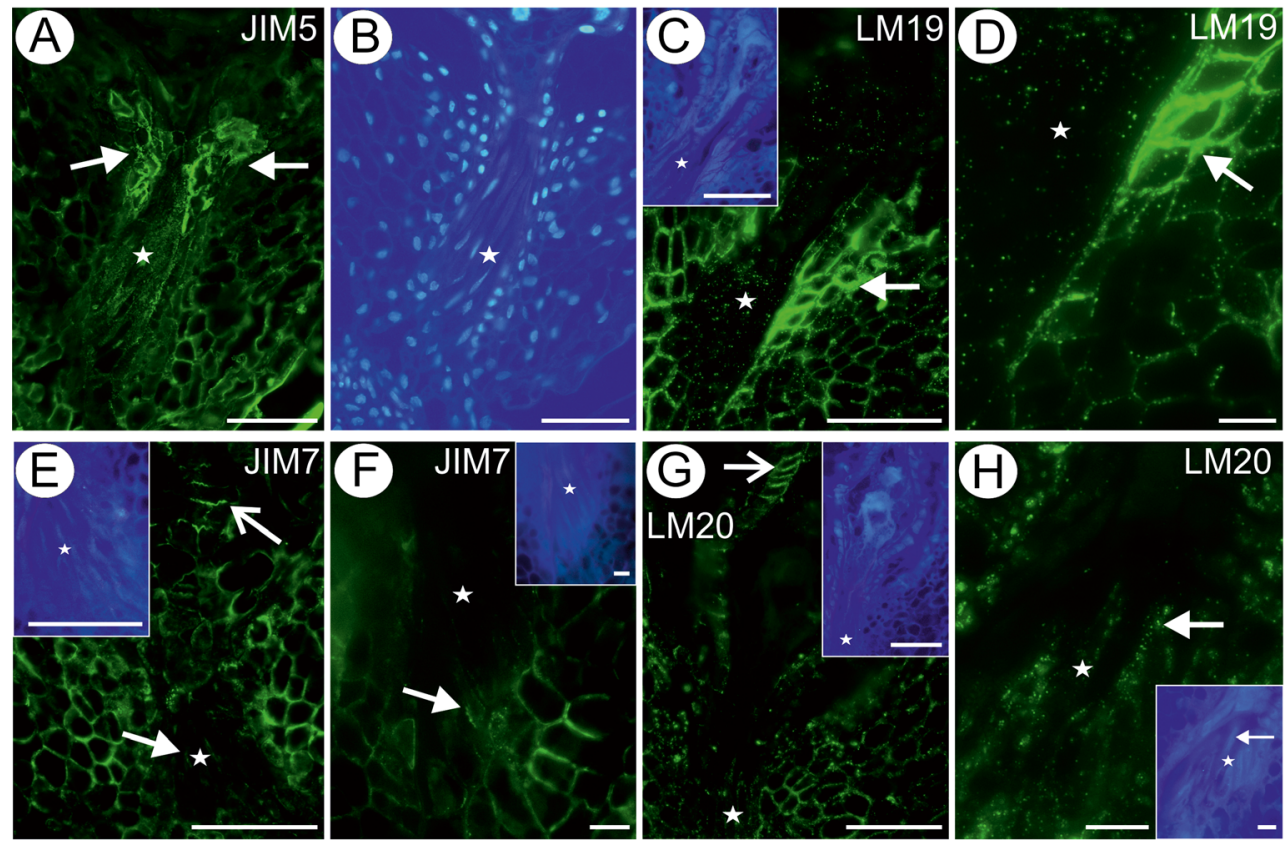

Fig. 6 Pectin detection in a young seed containing an embryo and endosperm. a Distribution of the JIM5 antibody in micropylar transmitting tissue cells and in the integument cells (arrows) near the synergids, $b a r=50 \mu \mathrm{m}$. b The same as a but nuclei visualisation, DAPI staining, bar $=50 \mu \mathrm{m}$. c Distribution of the LM19 antibody in micropylar transmitting tissue cells; arrow points to the cell walls of some integumentary cells in the vicinity of micropylar transmitting tissue cells, bar $=50 \mu \mathrm{m}$; inset cellulose visualisation, bar $=50 \mu \mathrm{m}$. d Higher magnification of $\mathbf{c}$, bar $=10 \mu \mathrm{m}$. e Distribution of the JIM7 antibody. Note the weak signal in the transmitting tissue (white star), but the stronger signal in the integumentary cell walls (open arrow); arrow

developed integument mucilage cells (Płachno et al. 2015a), and their cytoplasm was rich in ribosomes.

In all of the amphimictic species studied, a strong accumulation of the arabinogalactan proteins (both the JIM13 and JIM8 epitopes or only JIM13) was recorded in the filiform apparatus of synergids (Pennell et al. 1991; Chudzik et al. 2005a, b; Coimbra and Salema 1997; Coimbra et al. 2007). In contrast, we did not observe such an accumulation of

points to the signal located in the cell wall of transmitting tissue (inset cellulose visualisation; $b a r=50 \mu \mathrm{m}), b a r=50 \mu \mathrm{m}$. $\mathbf{f}$ The presence of the JIM7 antibody in the walls (arrow) of transmitting tissue cells (star); inset cellulose visualisation, bar $=10 \mu \mathrm{m}$. g Distribution of the LM20 antibody (open arrow points to the anticlinal walls of the inner integumentary epidermal cells). Note the presence of this pectic epitope in the walls of different ovule tissues, but weaker signal in the transmitting tissue cells (star). Inset cellulose visualisation, $b a r=50 \mu \mathrm{m}$. h Another example of the presence of the LM20 antibody in transmitting tissue cell walls (arrow). Inset cellulose visualisation, bar $=10 \mu \mathrm{m}$

arabinogalactan proteins (JIM13) in the filiform apparatus of Taraxacum synergids. However, weak labelling was observed in the synergid walls (including the filiform apparatus) and the cytoplasmic compartments. There can be a few explanations for this phenomenon, e.g. the structure of the filiform apparatus in Taraxacum or the apomictic mode of reproduction. Moreover, an accumulation of this AGP epitope may be correlated with pollination and the growth of pollen tubes in the

Fig. 7 Ultrastructure of integument cells in the micropylar pole near the egg apparatus. a, b Cells that border mucilage cells, note the cytoplasm rich in ribosomes, well-developed rough endoplasmic reticulum $(E R)$ and non-hypertrophied dictyosomes (arrows). Vacuole with small vesicles (star), mucilage layer $(m), b a r=1.3$ and $1 \mu \mathrm{m}$. c Mucilage cell, note the mucilage layer $(m)$ between the plasmalemma and cell wall, hypertrophied dictyosomes (arrows), membranous vacuolar inclusion (star), bar $=0.85 \mu \mathrm{m}$

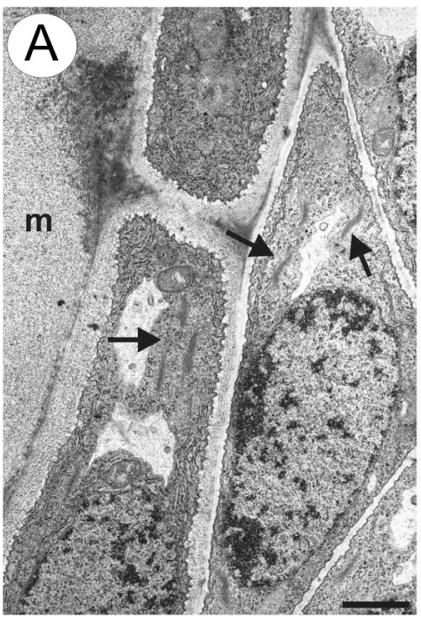

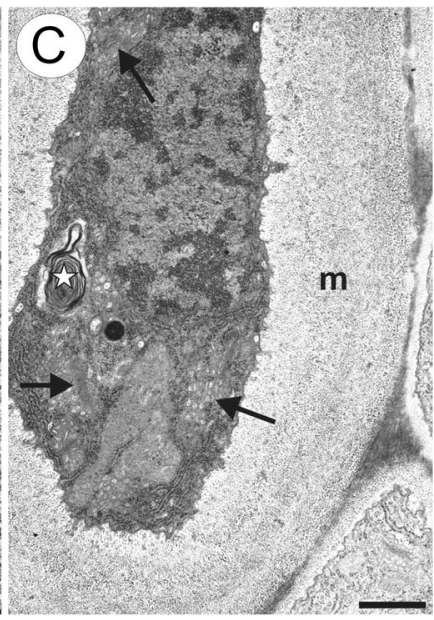


style; e.g. AGP epitopes were not detected in open but unpollinated flowers of Galanthus ovules (Chudzik et al. 2005a, b). In Taraxacum (Płachno et al. 2014) as in other Asteraceae (e.g. Helianthus, Newcomb 1973; Yan et al. 1991), the thickened adjacent walls of both synergids build the filiform apparatus. This Asteraceae type of filiform apparatus is different from the classical filiform apparatus, which comprises an elaborate system of highly branched projections (Huang and Russell 1992) and in which a strong accumulation of arabinogalactan protein was found. Unfortunately, to date, only two species from the Asteraceae family have been studied to analyse the occurrence of AGPs in the embryo sac and ovule. According to Chudzik et al. (2010), in the mature ovules in amphimictic B. perennis, the AGPs that were recognised by the JIM13 and JIM16 antibodies were distributed in the cell walls of the embryo sac and egg apparatus, but the MAC207 epitope did not occurred in the female gametophyte. In the apomict $C$. juncea, the AGP epitope recognised by the JIM13 antibody was not recorded in the micropylar canal or the mature embryo sac (Chudzik et al. 2005a). Kościńska-Pająk and co-authors (2005), Kościńska-Pająk (2006), Kościńska-Pająk and Bednara (2006) and Chudzik et al. (2005a) suggested that the synergids in obligatory apomicts are in the juvenile phase and do not show the secretory activity that is characteristic of amphimictic plants. In contrast to Chondrilla, the cytoplasm in the apomictic Taraxacum synergids contained arabinogalactan proteins labelled by JIM13 and JIM16 antibodies. Pennell et al. (1991) showed that arabinogalactan proteins occurred in Golgi-derived vesicles in the synergids of Brassica. Thus, we propose that AGP recognised by the JIM16 antibody may be a useful marker for the borders between the cells of the egg apparatus and the central cell. The whole embryo sac was labelled with JIM13 in Sinapis alba (Chudzik et al. 2005b), while not only the synergids but also the cell walls of the central cell were labelled with JIM13 in Arabidopsis (Coimbra et al. 2007). We made a similar observation in the case of Taraxacum, in which the arabinogalactan proteins occurred in the central cell cytoplasm (localisation within the cytoplasm endomembrane system) and walls.

To summarise, the AGPs that occur along the pathway of pollen tube growth in amphimictic (sexual) plants may also occur in similar places in apomicts as we showed in Taraxacum. The relationship between the occurrence of AGPs and the pathway of pollen tube growth is very conservative in evolutionary terms because AGPs have also been detected between the nucellus cells in gymnosperm ovules (Rafińska and Bednarska 2011).

\section{Pectins}

Pectins are diverse wall chemical components (Caffall and Mohnen 2009; Palmer et al. 2015) and are considered to be determinants in plant development and plant tissue differentiation (e.g. Wolf et al. 2009). It has been well documented that homogalacturonan $(\mathrm{HG})$ plays an important role in pollenstigma and pollen tube-pistil interactions in flowering plants (see Sage et al. 2009; Niedojadło et al. 2015 and discussion therein). In amphimictic plants, there are pollination- and fertilisation-induced changes in the occurrence of highly (JIM7) and low (JIM5) methyl-esterified pectins in the pistil transmitting tract, the micropyle of the ovule and also in the apoplast of female gametophyte cells (Lenartowska et al. 2001; Śnieżko and Chudzik 2003; Suárez et al. 2013; Niedojadło et al. 2015). In contrast to amphimictic plants (e.g. Galanthus, Śnieżko and Chudzik 2003; Olea, Suárez et al. 2013; Hyacinthus, Niedojadło et al. 2015), we did not observed abundant occurrence of highly methyl-esterified HG labelled by the JIM7 antibody in either the micropyle or the synergids of apomictic Taraxacum. Neither of the two HG domains (recognised by JIM7 and JIM5 antibodies) were recorded in the micropylar part of the embryo sac nor in the cytoplasm of the synergids in apomict $C$. juncea (Kościńska-Pająk et al. 2005; Kościńska-Pająk 2006). In transmitting tissues of Taraxacum, the JIM5 epitope was present in both analysed developmental stages, but the JIM7 epitope was detected only in the stage of the young seed. These pectins also occurred in Taraxacum in the filiform apparatus of the synergids. There is rearrangement of the HG presence in transmitting tissue during ovule maturation and the stages of pollination in amphimictic plants. In apomictic Taraxacum, the similar pattern of low methyl-esterified HG characterised both developmental stages. The presence of high methylesterified pectins appeared with the more advanced stage of development.

Differences which we found in the presence of pectic epitopes recognised by JIM5, JIM7, LM19 and LM20 antibodies depended most probably on the range of epitopes they recognised. In general, some similarities between these epitope pairs are described (Verhertbruggen et al. 2009). In our case, it is visible that JIM7 and LM20 epitopes occur in the similar manner in the parenchymatic tissue of the ovule or in the integument tapetum (Figs. 3e, g and 6e, g); however, differences are found in the epidermal tissue of ovule where LM20 occurs abundantly in contrast to JIM7 (Fig. 3e and inset) or in transmitting tissue (Figs. 3 and 6). JIM5 and LM19 occurrence is also consistent with two differences in epitope distribution: the LM19 epitope occurs often in a more punctate manner than JIM5, and JIM5 occurs more abundantly in the walls of transmitting tissue (compare Figs. 3 and 6).

The occurrence of pectin epitopes with a low degree of esterification in the cytoplasm is rather unexpected as HG is synthesised in a highly methyl-esterified form in the Golgi apparatus (Bárány et al. 2010). Such result may indicate the artefacts or the presence of pectin detected with the use of JIM5 antibody within the cytoplasmic compartments. The 
presence of JIM5 epitope in the cytoplasm is seldom described in the literature. In the case of Arabidopsis thaliana protoplasts, the presence of JIM5 antibody within the cytoplasm was described together with the wall-associated kinases (Kohorn et al. 2006). Another example comes from studies on stylar transmitting tissues in Brugmansia suaveolens (Hudák et al. 1993), where it was shown on the transmission electron microscopy level that pectic epitope recognised by the JIM5 antibody was present in the cytoplasmic membrane system, mostly in ER, AG and multivesicular bodies, and the distribution changed depending on the developmental stage. Thus, the results presented here may be another example of the presence of low methyl-esterified pectins not only in the cell wall but also in the cytoplasm compartments. Another explanation of this result is that both JIM5 and JIM7 antibodies have a rather big set of common elements (Knox et al. 1990; Willats et al. 2000; Clausen et al. 2003). Therefore, the JIM5 antibody may also detect some pectic epitopes recognised by the JIM7 antibody.

\section{Hemicelluloses}

Hemicelluloses are polysaccharides that are involved in the cross-linking of cellulose microfibrils (Scheller and Ulvskov 2010; Palmer et al. 2015). The hemicellulose content and deposition within the cell wall change, and it is postulated that this chemical component plays a specific role in the wall matrices during cell wall formation and development (Palmer et al. 2015). Studies with the more recently generated LM25 xyloglucan antibody and the LM21 heteromannan antibody showed a differential presence of these hemicelluloses in the cell walls of wheat and rice undergoing cellularisation in the syncytial endosperm (Palmer et al. 2015). The analyses presented here showed a differential distribution of xyloglucan and heteromannan since the first one was detected in the integumentary epidermis near the apex of the embryo sac and in the cytoplasm and extracellular matrix of the transmitting tissue cells, and the second one was detected in the walls of the transmitting tissue cells and in some integument cells (where it may also occur in the cytoplasm) near the embryo sac and the micropylar canal. To date, the distribution of hemicelluloses has only been analysed on the example of barley, wheat and rice during cellularisation (Wilson et al. 2012; Palmer et al. 2015) and it is difficult to compare our results with the literature. It is postulated (Palmer et al. 2015) that hemicellulose polysaccharides may influence the plasticity of the cell wall, thus allowing the cells to respond to the rapid changes during the development of the cell wall or that they may represent a more easily digestible storage medium than microfibril cellulose (Palmer et al. 2015), which in the case of Taraxacum requires further studies.

In conclusion, our findings reveal that an accumulation of arabinogalactan proteins (AGPs) and some pectic epitopes occurred in the micropylar transmitting tissue of apomictic Taraxacum, which is similar to the micropylar ovule tissues of other sexual plant species. There is rearrangement of HG during ovule maturation and the stages of pollination in amphimictic plants. This is the first time that data about the occurrence of hemicelluloses (LM25 and LM21) in the reproductive structure of flowering plants are presented in the literature. Moreover, the accumulation of both, low methylesterified HG (JIM5, LM19) and AGP (JIM13), occurred in the integument cells surrounding the micropylar canal near the synergids. Such a diverse description of the presence of different pectic, AGP and hemicellulose epitopes is presented in a spatio-temporal manner on the example of apomict plants for the first time (at least to authors' knowledge).

Acknowledgments This research was partially supported financially by the Ministry of Science and Higher Education of Poland as part of the statutory activities of the Department of Cell Biology, University of Silesia, and was also partially funded by the National Science Centre, Poland (contract grant number DEC-2013/09/B/NZ8/03308 in case BJP).

\section{Compliance with ethical standards}

Conflict of interest The authors declare that they have no conflict of interest.

Open Access This article is distributed under the terms of the Creative Commons Attribution 4.0 International License (http:// creativecommons.org/licenses/by/4.0/), which permits unrestricted use, distribution, and reproduction in any medium, provided you give appropriate credit to the original author(s) and the source, provide a link to the Creative Commons license, and indicate if changes were made.

\section{References}

Bárány I, Fadón B, Risueño MC, Testillano PS (2010) Cell wall components and pectin esterification levels as markers of proliferation and differentiation events during pollen development and pollen embryogenesis in Capsicum annuum L. J Exp Bot 61:1159-1175

Caffall KH, Mohnen D (2009) The structure, function, and biosynthesis of plant cell wall pectic polysaccharides. Carbohydr Res 344:1879 1900

Chudzik B (2002) Procesy determinujące receptywność zalążków o różnej budowie anatomicznej u roślin z rodzin: Amaryllidaceae, Brassicaceae, Liliaceae i Oenotheraceae. $\mathrm{PhD}$ thesis, MCSU in Lublin.

Chudzik B, Kościńska-Pająk M, Śnieżko R (2005a) Immunodetection of arabinogalactan proteins (AGPs) in apomictic ovules of Chondrilla juncea L. Acta Biol Cracov Bot 47:35

Chudzik B, Zarzyka B, Śnieżko R (2005b) Immunodetection of arabinogalactan proteins in different types of plant ovules. Acta Biol Cracov Bot 47:139-146

Chudzik B, Burlik M, Zarzyka B, Szczuka E (2010) Localization of arabinogalactan proteins during development of gametophytes in Bellis perennis L. Acta Biol Cracov Bot 52:52 
Chudzik B, Szczuka E, Zarzyka B, Leszczuk A (2014) Distribution of arabinogalactan proteins during microsporogenesis in the anther of Bellis perennis (Asteraceae) L. Acta Biol Cracov Bot 56:49-60

Clausen HM, Willats WGT, Knox JP (2003) Synthetic methyl hexagalacturonate hapten inhibitors of anti-homogalacturonan monoclonal antibodies LM7, JIM5 and JIM7. Carbohydr Res 338: $1797-1800$

Coimbra S, Duarte C (2003) Arabinogalactan proteins may facilitate the movement of pollen tubes from the stigma to the ovules in Actinidia deliciosa and Amaranthus hypochondriacus. Euphytica 133:171178

Coimbra S, Salema R (1997) Immunolocalization of arabinogalactan proteins in Amaranthus hypochondriacus L. ovules. Protoplasma 199:75-82

Coimbra S, Almeida J, Junqueira V, Costa ML, Pereira LG (2007) Arabinogalactan proteins as molecular markers in Arabidopsis thaliana sexual reproduction. J Exp Bot 58:4027-4035

Coimbra S, Jones B, Pereira LG (2008) Arabinogalactan proteins (AGPs) related to pollen tube guidance into the embryo sac in Arabidopsis. Plant Signal Behav 3:455-456

Costa M, Pereira AM, Rudall PJ, Coimbra S (2013) Immunolocalization of arabinogalactan proteins (AGPs) in reproductive structures of an early-divergent angiosperm, Trithuria (Hydatellaceae). Ann Bot 111:183-190

Funk VA, Susanna A, Stuessy TF, Robinson H (2009) Classification of Compositae. In: Funk VA, Susanna A, Stuessy T, Bayer R (eds) Systematics, evolution, and biogeography of the Compositae. IAPT, Vienna, pp 171-189

Huang B-Q, Russell SD (1992) Female germ unit: organization, isolation, and function. Int Rev Cytol 140:233-292

Hudák J, Walles B, Vennigerholz F (1993) The transmitting tissue in Brugmansia suaveolens L.: ultrastructure of the stylar transmitting tissue. Ann Bot 71:177-186

Khosravi D, Joulaie R, Shore JS (2003) Immunocytochemical distribution of polygalacturonase and pectins in styles of distylous and homostylous Turneraceae. Sex Plant Reprod 16:179-190

Knox JP, Linstead PJ, King J, Cooper C, Roberts K (1990) Pectin esterification is spatially regulated both within cell walls and between developing tissues of root apices. Planta 181:512-521

Knox JP, Linstead PJ, Peart J, Cooper C, Roberts K (1991) Developmentally regulated epitopes of cell surface arabinogalactan proteins and their relation to root tissue pattern formation. Plant $\mathrm{J} 1$ : 317-326

Kohorn BD, Kobayashi M, Johansen S, Friedman HP, Fischer A, Byers N (2006) Wall-associated kinase 1 (WAK1) is crosslinked in endomembranes, and transport to the cell surface requires correct cell-wall synthesis. J Cell Sci 119:2282-2290

Kościńska-Pająk M (2006) Biologia rozmnażania apomiktycznych gatunków Chondrilla juncea L., Chondrilla brevirostris L. i Taraxacum alatum Lindb. z uwzgleednieniem badań ultrastrukturalnych i immunocytochemicznych. KonTekst, Kraków

Kościńska-Pająk M, Bednara J (2006) Unusual microtubular cytoskeleton of apomictic embryo sac of Chondrilla juncea L. Protoplasma 227:87-93

Kościńska-Pająk M, Chudzik B, Zarzyka B, Pawelec J (2005) Structural and biochemical changes in the micropylar region of Chondrilla juncea apomictic ovule. Acta Biol Cracov Bot 47:66

Lenartowska M, Rodríguez-García MI, Bednarska E (2001) Immunochemical localization of esterified and unesterified pectins in unpollinated and pollinated styles of Petunia hybrida Hort. Planta 213:182-191

Lord EM (2003) Adhesion and guidance in compatible pollination. J Exp Bio 54:47-54

Lord EM, Russell SD (2002) The mechanisms of pollination and fertilization in plants. Annu Rev Cell Dev Bi 18:81-105
Lyew J, Li Z, Yuan LC, Luo YB, Sage TL (2007) Pollen tube growth in association with a dry-type stigmatic transmitting tissue and extragynoecial compitum in the basal angiosperm Kadsura longipedunculata (Schisandraceae). Am J Bot 94:1170-1182

Małecka J (1973) Problems of the mode of reproduction in microspecies of Taraxacum section Palustria Dahlstedt. Acta Biol Cracov Bot 16: $37-84$

Marcus SE, Blake AW, Benians TAS, Lee KJD, Poyser C, Donaldson L, Leroux O, Rogowski A, Petersen HL, Boraston A, Gilbert HJ, Willats WGT, Knox JP (2010) Restricted access of proteins to mannan polysaccharides in intact plant cell walls. Plant J 64:191-203

Mártonfiová L (2006) Possible pathways of the gene flow in the genus Taraxacum section Ruderalia. Folia Geobot 41:183-201

Newcomb W (1973) The development of the embryo sac of sunflower Helianthus annuus before fertilization. Can J Bot 51:863-878

Niedojadło K, Hyjek M, Bednarska-Kozakiewicz E (2015) Spatial and temporal localization of homogalacturonans in Hyacinthus orientalis L. ovule cells before and after fertilization. Plant Cell Rep 34:97-109

Palmer R, Cornuault V, Marcus SE, Knox JP, Shewry PR, Tosi P (2015) Comparative in situ analyses of cell wall matrix polysaccharide dynamics in developing rice and wheat grain. Planta 241:669-685

Pedersen HL, Fangel JU, McCleary B, Ruzanski C, Rydah MG, Ralet MC, Farkas V, Schantz L, Marcus SE, Andersen MC, Field R, Ohlin M, Knox JP, Clausen MH, Willats WGT (2012) Versatile high resolution oligosaccharide microarrays for plant glycobiology and cell wall research. J Biol Chem 287:39429-39438

Pennell RI, Janniche L, Kjellbom P, Scofield GN, Peart JM, Roberts K (1991) Developmental regulation of a plasma membrane arabinogalactan protein epitope in oilseed rape flowers. Plant Cell 3:1317-1326

Płachno BJ, Musiał K, Świątek P, Tuleja M, Marciniuk J, GrabowskaJoachimiak A (2014) Synergids and filiform apparatus in the sexual and apomictic dandelions from section Palustria (Taraxacum, Asteraceae). Protoplasma 251:211-217

Płachno BJ, Świątek P, Kozieradzka-Kiszkurno M, Majeský L, Marciniuk J, Stolarczyk P (2015a) Are obligatory apomicts invested in the pollen tube transmitting tissue? Comparison of the micropyle ultrastructure between sexual and apomictic dandelions (Asteraceae, Lactuceae). Protoplasma 252:1325-1333. doi:10.1007/s00709-0150765-x

Płachno BJ, Kurczyńska E, Świątek P (2015b) Integument cell differentiation in dandelions (Taraxacum, Asteraceae, Lactuceae) with special attention paid to plasmodesmata. Protoplasma. doi:10.1007/ s00709-015-0894-2

Potocka I, Baldwin TC, Kurczynska EU (2012) Distribution of lipid transfer protein 1 (LTP1) epitopes associated with morphogenic events during somatic embryogenesis of Arabidopsis thaliana. Plant Cell Rep 31:2031-2045

Rafińska K, Bednarska E (2011) Localisation pattern of homogalacturonan and arabinogalactan proteins in developing ovules of the gymnosperm plant Larix deciduas Mill. Sex Plant Reprod 24:75-87

Rumyantseva NI (2005) Arabinogalactan proteins: involvement in plant growth and morphogenesis. Biochemistry (Moscow) 70:1073-1085

Sage TL, Hristova-Sarkovski K, Koehl V, Lyew J, Pontieri V, Bernhardt P, Weston P, Bagha S, Chiu G (2009) Transmitting tissue architecture in basal-relictual angiosperms: implications for transmitting tissue origins. Am J Bot 96:183-206

Sala K, Potocka I, Kurczynska E (2013) Spatio-temporal distribution and methyl-esterification of pectic epitopes provide evidence of developmental regulation of pectins during somatic embryogenesis in Arabidopsis thaliana. Biol Plantarum 57:410-416

Šamaj J, Baluška F, Bobák M, Volkmann D (1999) Extracellular matrix surface network of embryogenic units of friable maize callus contains arabinogalactan-proteins recognized by monoclonal antibody JIM4. Plant Cell Rep 18:369-374 
Scheller HV, Ulvskov P (2010) Hemicelluloses. Annu Rev Plant Biol 61: 263-289

Seifert GJ, Roberts K (2007) The biology of arabinogalactan proteins. Annu Rev Plant Biol 58:137-61

Śnieżko R, Chudzik B (2003) The ovule as an active partner in sexual reproduction of flowering plants. (In Polish). Kosmos 52:445-457

Suárez C, Zienkiewicz A, Castro AJ, Zienkiewicz K, Majewska-Sawka A, Rodríguez-García MI (2013) Cellular localization and levels of pectins and arabinogalactan proteins in olive (Olea europaea L.) pistil tissues during development: implications for pollen-pistil interaction. Planta 237:305-319

Tchorbadjieva MI (2005) Protein markers for somatic embryogenesis. In: Mujib A, Šamaj J (eds) Somatic embryogenesis. Springer, Berlin, pp 215-233

Tilton VR, Horner HT (1980) Stigma, style and obturator of Ornithogalum caudatum (Liliaceae) and their function in the reproductive process. Am J Bot 67:1113-1131

van Baarlen P, de Jong JH, van Dijk PJ (2002) Comparative cytoembryological investigations of sexual and apomictic dandelions (Taraxacum) and their apomictic hybrids. Sex Plant Reprod 15:31-38

van Hengel AJ, van Kammen A, de Vries SC (2002) A relationship between seed development, arabinogalactan-proteins (AGPs) and the AGP mediated promotion of somatic embryogenesis. Physiologia Plantarum 114:637-644

Vasil IK, Johri MM (1964) The style, stigma and pollen tube. I Phytomorphology 14:352-369

Verhertbruggen Y, Marcus SE, Haeger A, Ordaz-Ortiz JJ, Knox JP (2009) An extended set of monoclonal antibodies to pectic homogalacturonan. Carbohyd Res 344:1858-1862

Vitha S, Baluska F, Jasik J, Volkmann D, Barlow PW (2000) Steedman's wax for F-actin visualization. In: Staiger CJ, Baluska F, Volkmann D, Barlow PW (eds) Actin: a dynamic framework for multiple plant cell function. Kluwer Academic, Dordrecht, pp 619-636
Willats WGT, Limbergb G, Buchholtc HC, van Alebeekd G, Benene J, Christensenb TMIE, Vissere J, Voragend A, Mikkelsenb JD, Knoxa JP (2000) Analysis of pectic epitopes recognised by hybridoma and phage display monoclonal antibodies using defined oligosaccharides, polysaccharides and enzymatic degradation. Carbohydr Res 327:309-320

Willats WGT, McCartney L, Steele-King CG, Marcus SE, Mort A, Huisman M, van Alebeek GJ, Schols HA, Voragen AG, Le Goff A, Bonnin E, Thibault J, Knox JP (2004) A xylogalacturonan epitope is specifically associated with plant cell detachment. Planta 218:673-681

Wilson SM, Burton RA, Collins HM, Doblin MS, Pettolino FA, Shirley N, Fincher GB, Bacic A (2012) Pattern of deposition of cell wall polysaccharides and transcript abundance of related cell wall synthesis genes during differentiation in barley endosperm. Plant Physiol 159:655-670

Wilson MH, Holman TJ, Sørensen I, Cancho-Sanchez E, Wells DM, Swarup R, Knox JP, Willats WGT, Ubeda-Tomás S, Holdsworth M, Bennett MJ, Vissenberg K, Hodgman TC (2015) Multi-omics analysis identifies genes mediating the extension of cell walls in the Arabidopsis thaliana root elongation zone. Front Cell Dev Biol. doi: 10.3389 /fcell.2015.00010

Wiśniewska E, Majewska-Sawka A (2006) Cell wall polysaccharides in differentiating anthers and pistils of Lolium perenne. Protoplasma 228:65-71

Wolf S, Mauille G, Pelloux J (2009) Homogalacturonan methylesterification and plant development. Mol Plant 2:851-860

Wu H, Wong E, Ogdahl J, Cheung AY (2000) A pollen tube growth promoting arabinogalactan protein from Nicotiana alata is similar to the tobacco TTS protein. Plant J 22:165-176

Yan H, Yang H, Jensen W (1991) Ultrastructure of the micropyle and its relationship to pollen tube growth and synergid degeneration in sunflower. Sex Plant Reprod 4:166-175 